\title{
Effect Of Banana Peel Flour Infusion On Serum LDL Levels Of Male Wistar Rat Given Heated Cooking Oil
}

\section{Pengaruh Pemberian Seduhan Tepung Kulit Pisang Kepok Terhadap Kadar LDL Serum Tikus Putih (Rattus Norvegicus Strain Wistar) Jantan Yang Diberi Minyak Jelantah}

\author{
Ilmi Dewi Astuti1*, Fuadiyah Nila Kurniasari², Yosfi Rahmi² \\ ${ }^{1}$ Nutrition Science Study Program, Banyuwangi Institute of Health Science, Banyuwangi, East Java \\ ${ }^{2}$ Nutrition Science Study Program, Faculty of Medicine, Brawijaya University, Malang, East Java \\ *Correspondence email: ilmidewi@stikesbanyuwangi.ac.id
}

\begin{abstract}
Atherosclerosis is a progressive disease causing a coronary heart disease (CHD). Atherosclerosis is related to the levels of LDL in the blood. An increased LDL in the blood can be prevented by consuming soluble fiber and antioxidants from such Kepok banana peels. The aim of this study is to know the effects of Kepok banana peel flour infusion in various dosage on LDL serum level of male wistar rats which were treated with a repeatedly heated cooking oil. This study used post test control group as experimental design in which 24 male rats were randomly categorized in five groups, namely (1) a negative control group, (2) a positive control group treated with a repeatedly heated cooking oil and distilled water, as well as the groups treated with a repeatedly heated cooking oil and $0.5,1$, and $2 \mathrm{ml} / \mathrm{rats}$ of Kepok banana peel flour solution, for group (3), (4), and (5) respectively. LDL level were measured by using calorimetric method. The result of this study showed that the highest average levels of LDL obtained in control positive group $K(+)$ was 14,25 $\mathrm{mg} / \mathrm{dl}$ and the lowest average level of LDL obtained in the group treated with a repeatedly heated cooking oil and $0.5 \mathrm{ml} / \mathrm{rat}$ was 11,2 $\mathrm{mg} / \mathrm{dl}$. It can be concluded that Kepok banana peel flour cannot significantly reduce the mean of LDL serum level of male Wistar rats treated with repeatedly heated cooking oil $(p>0,05)$.
\end{abstract}

Key Words: LDL level, repeatedly heated cooking oil, Kepok banana peel flour solution

\section{INTRODUCTION}

Diet greatly determines a person's health condition. Currently eating patterns have changed, people prefer to consume fast food (fast food) and food cooked by frying (Yahya et al., 2013). The use of oil repeatedly when frying will increase the amount of oxidized fat and reduce the amount of antioxidants contained in the oil so that the number of free radicals increases and will induce oxidative stress which plays an important role in the development of atherosclerosis (Jaarin et al., 2006.; Xian et al., 2012).

Atherosclerosis is a disease in which plaque builds up in the arteries. Excessive plaque buildup will make arteries harden and narrow, causing blood flow to the heart and other organs to be disrupted. The process of atherosclerosis that occurs in the blood vessels of the heart can trigger coronary heart disease, if it occurs in the blood vessels of the brain it can cause a stroke (brain disorder due to lack of blood flow) (USDA 2020).

Treatment for atherosclerosis may involve medication, diet or exercise which basically lowers blood cholesterol levels. One of the ingredients in foods that can be used to lower cholesterol in the blood is fiber. Fiber is divided into 2 groups, namely soluble fiber and insoluble fiber. Fiber that can be dissolved in water for example is pectin, gum, mukilase, 
glucan and algae. Soluble fiber has the most effect in lowering blood cholesterol levels, while insoluble fiber in water has the least effect on reducing cholesterol levels in the blood (Santoso, 2011). The decrease in cholesterol levels can be seen from the decrease in LDL level accompanied by a decrease in cholesterol levels in the liver and tissues (Almatsier, 2002).

One of the fruits that are rich in fiber is Kepok banana. Kepok banana peel can be used because it contains pectin which is a type of water soluble fiber which is higher than other fruits. The pectin content in kepok banana peels ranges from $10-21 \%$ or about $13-21.7$ g/100 g of dry weight (Wachirasiri et al., 2009; Wangeci, 2011).

Kepok banana peels also have antioxidant activity which can also play a role in reducing LDL levels in the blood by binding to cholesterol that should bind to bile acids, so that cholesterol cannot enter the mucous membrane of the small intestine and eventually comes out with feces (Vinarova et al., 2015). Research conducted by Atun et al (2007) on the antioxidant activity of Kepok banana peels proved that Kepok banana peel extract was able to inhibit $50 \%$ oxidation only at a concentration of $693.15 \mathrm{mg} / \mathrm{ml}$ (Atun et al., 2010). It is showing the activity of antioxidant in Kepok banana peels much higher than Ambon banana peels, where research on Ambon banana showed that extracts of Ambon banana peel can inhibit $50 \%$ oxidation at a concentration of $5000 \mathrm{ug} / \mathrm{ml}$ (Imam et al., 2011). If this banana peel powdered, antioxidant activity still remains relatively high namely $72,92 \%$ (Nuramanah Hayat; Siswaningsih, Wiwi, 2013).

This study aimed to see the effect of Kepok banana peel flour on LDL levels in male white rats (Rattus norvegicus Strain Wistar) given cooking oil.

\section{METHODS}

This research is a true experimental study ( post test control group design ). The sample in this study was 25 male wistar rats (Rattus norvegicus Wistar Strain) that met the inclusion criteria, namely male sex , age 6-8 weeks, body weight 100-250 g, complete limbs, no defects, active movement, clear eyes, clean white fur. Rats were housed in lightcontrolled environment with food and water provided ad libitum. In this study, the sample was divided into 5 groups with 5 rats in each group, namely a negative control group, a positive control group and three treatment groups. All experiments described here were approved by Brawijaya University Ethical Clearence.

\section{Making Kepok Banana Peel Flour}

Kepok banana peels washed clean, then soaked in a solution of salt 0,3\% for 10 minutes to reduce enzymatic browning. Kepok banana peels then cut in squares measuring $\pm 1 \mathrm{~cm} \times 1 \mathrm{~cm}$. Then it arranged in a baking dish and ready to be dried using an oven with a temperature of $600 \mathrm{C}$ for 2,5-3 hours. After drying, Kepok banana peel was crushed using a dry blender and then sifted with a 100 mesh sieve to become a flour.

\section{Experimental Design.}

In this study, rats were divided into 5 groups, namely:

1. Negative control group (K-) : the group that was given a normal diet +2 times sonde placebo aquades ( $\mathrm{n}=5$ per group)

2. Positive control group $(\mathrm{K}+)$ : the group that was given a normal diet + oil cooking 2 $\mathrm{ml} / \mathrm{rat}+1$ times sonde placebo aquades

3. P1: the group that was given a normal diet + heated cooking oil $2 \mathrm{ml} / \mathrm{rat}+\mathrm{Kepok}$ banana peel flour dose of $0.5 \mathrm{ml} / \mathrm{rat}$ 
4. P2: the group that was given a normal diet + heated cooking oil $2 \mathrm{ml} / \mathrm{rat}+\mathrm{Kepok}$ banana peel flour of $1 \mathrm{ml} / \mathrm{rat}$

5. P3: the group that was given a normal diet + heated cooking oil $2 \mathrm{ml} / \mathrm{rat}+\mathrm{Kepok}$ banana peel flour dose of $2 \mathrm{ml} /$ rat

Body weight and food consumption were measured daily. All rats were sacrificed after fasting overnight on day 15 of the experiment. Blood samples were centrifuged and the plasma was separated to measure LDL level. Results are given as mean \pm SD. Data were statistically analyzed using SPSS through normality test using the Shapiro-Wilk and followed by Kruskal -Wallis test .

\section{RESULTS AND DISCUSSION}

The highest average initial body weight was in the Treatment group P3 which is $200 \pm$ 28.52 grams, while the lowest was in the Treatment group which is $182.8 \pm 10.52$ grams. The highest average final body weight was found in the Positive Control group (K+) which is $239.2 \pm 42.87$ grams, while the lowest final body weight was in the Treatment group 2 (P2) which is $210.4 \pm 15.92$ grams. The highest average feed intake was shown by rats in the negative K(-) control group of 26.35 grams, while the lowest average feed intake was experienced by rats in the P2 treatment group of 22.32 grams.

\section{Rat Serum LDL Level}

Based on the results of the normality test by Shapiro Wilk, the data obtained from the results of rat serum LDL levels were not normally distributed, namely $p=0.001(p<0.05)$. Because the data obtained are not normally distributed, then the data transformation test is carried out and the results are still not normally distributed. Based on the results of statistical tests to test the homogeneity of the data on the average LDL level, the results obtained where $p=0.548(p>0.05)$ so that it can be concluded that the data has a homogeneous variant. Furthermore, statistical analysis using Kruskall Wallis was carried out and the results were $p=0.980$ which showed no difference because $p>0.05$. Because there was no difference, no further tests were carried out in the form of correlation and regression tests.

Although there was no significant difference, in Table 1 it can be seen that there was a decrease in the mean LDL level in the P1, P2, and P3 groups compared to the Negative Control group (K-) and the Positive Control group (K+). In this study, the P1 group had the lowest mean LDL level and the K+ group had the highest average LDL level. 
Table 1 Initial and Post-Treatment Body Weight, Average Intake of Rats, and Serum LDL Levels in Rats

\begin{tabular}{|c|c|c|c|c|c|}
\hline & K- & $\mathrm{K}+$ & P1 & P2 & P3 \\
\hline $\begin{array}{l}\text { Initial body } \\
\text { weight } \\
\text { (mean } \pm \text { SD) (g) }\end{array}$ & $\begin{array}{l}186.6 \pm \\
24.14\end{array}$ & $190.5 \pm 43.67$ & $191 \pm 21.38$ & $\begin{array}{l}182.8 \pm \\
10.52\end{array}$ & $200 \pm 28.52$ \\
\hline $\begin{array}{l}\text { Final body } \\
\text { weight } \\
\text { (mean } \pm \text { SD) }(g)\end{array}$ & $210.6 \pm 12.89$ & $\begin{array}{l}239.2 \pm \\
42.87\end{array}$ & $\begin{array}{l}226.8 \pm \\
26.04\end{array}$ & $210.4 \pm 15.92$ & $\begin{array}{l}237.2 \pm \\
38.47\end{array}$ \\
\hline $\begin{array}{l}\text { Average Intake } \\
\text { (g) }\end{array}$ & 26.35 & 24.93 & 24.25 & 22.32 & 26.07 \\
\hline $\begin{array}{l}\text { Mean LDL } \\
(\mathrm{mg} / \mathrm{dl})\end{array}$ & 13.2 & 14.25 & 11.2 & 11.8 & 13 \\
\hline $\begin{array}{l}\text { Median LDL } \\
\text { (mg/dl) }\end{array}$ & 13 & 13 & 10 & 10 & 11 \\
\hline $\begin{array}{l}\text { Min-max LDL } \\
(\mathrm{mg} / \mathrm{dl})\end{array}$ & $10-20$ & $9-22$ & $10-14$ & $8-17$ & $9-21$ \\
\hline $\begin{array}{l}\text { Standard } \\
\text { Deviation }\end{array}$ & 4.08 & 5.56 & 1.79 & 3.63 & 4.85 \\
\hline
\end{tabular}

\section{Sample characteristics}

The rats used in this study were male white rats, Rattus novergicus strain wistar, aged 6-8 weeks, weighing between 150-200 grams and in good health during the study. This study used 25 rats which were divided into 5 groups with different treatments with randomization techniques that allowed each rat to have the same opportunity to be the sample in the study.

Table 1 shows that the highest final body weight was in the Positive Control group (K+), which was $239.2 \pm 42.87 \mathrm{~g}$, while the lowest final body weight was in the P2 group, which was $210.4 \pm 15.92 \mathrm{~g}$. This might be due to the fact that the K(+) group was only given heated cooking oil which could increase the body weight of the rats, while the P2 group not only given heated cooking oil but also given Kepok banana peel flour. This can be caused by the presence of pectin in the kepok banana peel. Pectin is able to reduce or prevent weight gain. The higher the use of banana peels, the more weight gain decreases (TNI, 2013).

The highest mean feed intake was found in the negative K(-) control group, which was $26.35 \mathrm{~g}$, while the lowest average feed intake was found in the P2 treatment group of 22.32 gr. This can be caused by giving heated cooking oil which can cause a longer full effect (Irianto, 2007) . In addition, the banana peels contains serotonin compounds (Fitria v, 2013). Serotonin has a very vital function in balancing mood, and suppressing appetite (Istiharoh, 2010).

\section{Effect of Cooking Oil on Serum LDL Levels in Rats}

The results of the research that have been carried out show that the administration of heated cooking oil for 15 days can increase serum LDL levels compared to a normal diet. It can be seen in Table 1, the results of the analysis show that the average serum LDL level in the group given cooking oil $\mathrm{K}(+)$ is $1.05 \mathrm{mg} / \mathrm{dl}$ higher than the average serum LDL level in the group given the normal diet $\mathrm{K}(-)$, which is $13,2 \mathrm{mg} / \mathrm{dl}$, but based on statistical analysis there was no significant difference between the mean serum LDL levels in the $K(+)$ group and the $\mathrm{K}(-)$ group, namely $\mathrm{p}=0.753$.

Heated cooking oil which is rich in saturated fat can increase LDL levels by decreasing the regulation of LDL receptors and increasing LDL production (Gatto et al., 2002; Merchant 
et al., 2007; Sartika, 2008). In addition, trans fatty acids contained in heated cooking oil play a role in increasing LDL levels through the mechanism of inhibition of enzyme activity in lipid metabolism (fatty acid desaturase elongase and Lecithin Choleslerol Acyl Transferase/LCAT) (Sartika, 2008).

The normal threshold for LDL levels in rats is $2-27 \mathrm{mg} / \mathrm{dl}$. When compared with the normal threshold, the mean serum LDL levels of rats in the control group $\mathrm{K}(+)$ were still in the normal category. So it can be concluded, giving heated cooking oil for 15 days can increase LDL levels in rats, but the increase in LDL levels has not exceeded the normal threshold for LDL levels in rats.

The LDL levels of rats in the control group K(+) were still relatively normal, perhaps because the levels of free fatty acids in the heated cooking oil used in this study were not high enough to make the LDL of rat serum exceed the normal limit within 15 days.

However, the heated cooking oil in this study has been tested for the content of free fatty acids (FFA). The results of the FFA test showed that the FFA content in the used cooking oil was $4.95 \%$. This indicates that the oil is not safe to use for frying because it has exceeded the free fatty acid percentage threshold set by SNI 01-3741-2002 which contains the condition that the maximum free fatty acid content is $0.30 \%$.

Consumption of foods containing high levels of free fatty acids can increase LDL levels and reduce blood HDL levels (Sartika, 2010). In this study, serum LDL levels of rats in the control group $\mathrm{K}(+)$ increased compared to the control group $\mathrm{K}(-)$, although the increase was still within normal limits. The same thing was also found in a study conducted by Bogoriani (2015) where the increase in LDL was still in the normal area with $2.5 \mathrm{ml}$ of used cooking oil/day for 10 weeks in wistar rats (Wayan \& Ketut, 2015).

\section{Effect of Kepok Banana Flour against LDL levels on Serum Rats}

Kepok banana peel flour that used in this study was expected to prevent the increase in serum LDL levels. In this study, the lowest mean LDL level was found in the P1 treatment group, which was $11.2 \mathrm{mg} / \mathrm{dl}$. This can be caused by the content of Kepok banana peel flour, namely pectin as water soluble fiber and antioxidants in the form of saponins, tannins, flavonoids that can reduce serum LDL levels because they have the effect of lowering lipid profiles and reducing the risk of atherosclerosis by preventing LDL oxidation (Ibegbulem et al., 2013; TALA, 2009). 24,25 Pectin has the ability to inhibit the increase in LDL cholesterol levels through two mechanisms, namely by inhibiting the activity of the HMG-CoA reductase enzyme and inhibiting the formation of micelles which cause a decrease in cholesterol absorption (Gropper et al., 2008) .

In addition, from the results of the Kepok banana peel flour test at the FTP Laboratory of Brawijaya University, the IC50 of the Kepok banana peel was $0.00038 \mathrm{mg}$ or $3.8 \mathrm{~g}$ or 3.8 $\mathrm{ppm}$. This shows that kepok banana peel flour has a very strong antioxidant activity because it has an IC50 value of $<50 \mathrm{ppm}$ (Molyneux P, 2004).

The antioxidant content in Kepok banana peels is very diverse. In 100 grams of dry weight of Kepok banana peel there are $1.27 \mathrm{mg}$ of total carotene, $1.8 \mathrm{mg}$ of vitamin C, 680 mg of polyphenols, $818.75 \mathrm{mg}$ of flavonoids, $1114 \mathrm{mg}$ of tannins and $2400 \mathrm{mg}$ of saponins (Ngarajaiah, Shyamala Bellur and Prakash, 2011). Saponins can lower blood LDL cholesterol by binding with cholesterol that supposedly binds with bile acids, so cholesterol cannot get in the mucous membranes of the small intestine and finally out with feces (Vinarova et al., 2015). Tannins also have a mechanism similar to the saponins in a decrease in blood LDL that binds to bile acids and excreted through the feces (Zubaidah et al., 2014). Antioxidant compounds such as flavonoid can lowering blood LDL cholesterol by inhibit HMG-CoA Reductase. Inhibition of HMGCoA Reductase causes a decrease in cholesterol synthesis and 
increases the number of LDL receptors contained in the liver cell membranes and extrahepatic tissues so that total cholesterol levels decrease (Baskaran et al., 2015). In addition, flavonoids can reduce blood cholesterol levels by increasing the excretion of bile acids (Carvajal-Zarrabal et al., 2009).

Meanwhile, the P2 and P3 treatment groups had higher mean LDL levels than the P1 treatment groups, namely $11.8 \mathrm{mg} / \mathrm{dl}$ and $13 \mathrm{mg} / \mathrm{dl}$. This can be caused by the higher the dose given or at high concentrations, antioxidant compounds can turn into pro-oxidants, so that they can exacerbate oxidative damage caused by free radicals (Rahal et al., 2014).

In this study, there was no significant difference in serum LDL levels in rats. Pectin as a watersoluble fiber is not able to reduce LDL levels because the pectin dissolved in this solution is less than the pectin contained in the extract and in this solution not all active substances can be dissolved completely. The less pectin content will require a longer research time than the research time using the extract.

\section{CONCLUSION}

It can be concluded that the Kepok banana peel flour solution did not significantly reduce the mean serum LDL level of the male white rats (Rattus norvegicus Strain Wistar ) given heated cooking oil. Based on the results of this study, further research is needed on the content of specific active substances in Kepok banana peel flour with different doses and longer time to produce significant differences. In addition, it is necessary to examine the initial LDL levels of rats in future studies, so that they can be compared with LDL levels of rats after treatment.

\section{CONFLICT OF INTEREST}

The authors declare that there were no conflicts of interest in this study.

\section{REFERENCES}

Almatsier, S. (2002). Prinsip Dasar Ilmu Gizi. Gramedia Pustaka Utama.

Atun, S., Arianingrum, R., Handayani, S., Rudyansah, R., \& Garson, M. (2010). IDENTIFICATION AND ANTIOXIDANT ACTIVITY TEST OF SOME COMPOUNDS FROM METHANOL EXTRACT PEEL OF BANANA (Musa paradisiaca Linn.). Indonesian Journal of Chemistry, 7(1), 83-87. https://doi.org/10.22146/ijc.21718

Baskaran, G., Salvamani, S., Ahmad, S. A., Shaharuddin, N. A., Pattiram, P. D., \& Shukor, M. Y. (2015). HMG-CoA reductase inhibitory activity and phytocomponent investigation of Basella alba leaf extract as a treatment for hypercholesterolemia. Drug Design, Development and Therapy, 9, 509-517. https://doi.org/10.2147/DDDT.S75056

Carvajal-Zarrabal, O., Hayward-Jones, P. M., Orta-Flores, Z., Nolasco-Hipólito, C., BarradasDermitz, D. M., Aguilar-Uscanga, M. G., \& Pedroza-Hernández, M. F. (2009). Effect of hibiscus sabdariffa L. dried calyx ethanol extract on fat absorption-excretion, and body weight implication in rats. Journal of Biomedicine and Biotechnology, 2009. https://doi.org/10.1155/2009/394592

Fitria. (2013). Karakterisasi Pektin Hasil Ekstraksi dari Limbah Kulit Pisang Kepok (Musa 
balbisiana ABB). UIN Syarif Hidayatullah, Jakarta.

Gatto, L. M., Lyons, M. A., Brown, A. J., \& Samman, S. (2002). Trans fatty acids affect lipoprotein metabolism in rats. Journal of Nutrition, 132(6), 1242-1248. https://doi.org/10.1093/jn/132.6.1242

Gropper, S. S., Smith, J. L., \& Groff, J. L. (2008). Advanced Nutrition and Human Metabolism, Fifth Edition (5th ed.). Wadsworth Cengage Learning. https://doi.org/10.1111/j.17534887.1997.tb01621.x

Ibegbulem, C. O., Igwe, C. U., Eyong, E. U., Essien, E. U., Wegwu, M. O., \& Akachukwu, D. (2013). LDL-cholesterol Lowering Effect of Terminalia littoralis Decoction: Hypothesized Mechanisms. Pharmacologia, 4(1), 34-37. https://doi.org/10.5567/pharmacologia.2013.34.37

Imam, M. Z., Akter, S., Mazumder, M. E. H., \& Rana, M. S. (2011). Antioxidant activities of different parts of Musa sapientum L. ssp. sylvestris fruit. Journal of Applied Pharmaceutical Science, 1(10), 68-72.

Irianto. (2007). Panduan Gizi Lengkap Keluarga dan Olahragawan. Andi Offset.

Istiharoh. (2010). Jajanan Unik “Lumpia Bunglon” Berbahan Dasar Tepung Kulit Pisang.

Jaarin, K., Norhayati, M., Norzana, G., Nor Aini, U., \& Ima-Nirwana, S. (n.d.). Jaarin 2006.pdf.

Merchant, A. T., Anand, S. S., Kelemen, L. E., Vuksan, V., Jacobs, R., Davis, B., Teo, K., \& Yusuf, S. (2007). Carbohydrate intake and HDL in a multiethnic population. American Journal of Clinical Nutrition, 85(1), 225-230. https://doi.org/10.1093/ajcn/85.1.225

Molyneux P. (2004). The use of the stable free radical diphenylpicryl-hydrazyl (DPPH) for estimating anti-oxidant activity. Songklanakarin Journal of Science and Technology, 26(May), 211-219.

Ngarajaiah, Shyamala Bellur and Prakash, J. (2011). Chemical composition and antioxidant potential of peels from three varieties of banana. Asian Journal of Food and AgroIndustry, 4(01), 31-46.

Nuramanah Hayat; Siswaningsih, Wiwi, E. S. (2013). KAJIAN AKTIVITAS ANTIOKSIDAN KULIT PISANG RAJA BULU (MUSA PARADISIACA L. VAR SAPIENTUM) DAN PRODUK OLAHANNYA. Jurnal Sains Dan Teknologi Kimia, Vol 4, No 1 (2013): Jurnal Sains dan Teknologi Kimia. http://journal.fpmipa.upi.edu/index.php/JSTK/article/view/145

Rahal, A., Kumar, A., Singh, V., Yadav, B., Tiwari, R., Chakraborty, S., \& Dhama, K. (2014). Oxidative stress, prooxidants, and antioxidants: The interplay. BioMed Research International, 2014. https://doi.org/10.1155/2014/761264

Santoso, A. (2011). SERAT PANGAN (DIETARY FIBER) DAN MANFAATNYA BAGI KESEHATAN. Magistra, 75(11), 35-40. https://doi.org/10.1108/eb050265

Sartika, R. A. D. (2008). Pengaruh Asam Lemak Jenuh, Tidak Jenuh dan Asam Lemak Trans terhadap Kesehatan. Kesmas: National Public Health Journal, 2(4), 154. https://doi.org/10.21109/kesmas.v2i4.258

Sartika, R. A. D. (2010). Pengaruh Suhu Dan Lama Proses Menggoreng (Deep Frying) Terhadap Pembentukan Asam Lemak Trans. Makara Journal of Science, 13(1), 23-28. https://doi.org/10.7454/mss.v13i1.354

Services, U. S. D. of H. and H. (2020). At a Glance At a Glance. At a Glance : Atherosclerosis, 12(3), 1-2. https://www.ippf.org/sites/default/files/2020-07/At a Glance 2019.pdf

TALA. (2009). Manfaat Serat Bagi Kesehatan. Departemen Ilmu Gizi, Fakultas Kedokteran 
Universitas Sumatera Utara.

TNI, K. (2013). Pengaruh pemanfaatan kulit pisang yang difermentasi terhadap karkas broiler. Jurnal Ilmu Ternak Dan Veteriner, 18(2), 153-157.

Vinarova, L., Vinarov, Z., Atanasov, V., Pantcheva, I., Tcholakova, S., Denkov, N., \& Stoyanov, S. (2015). Lowering of cholesterol bioaccessibility and serum concentrations by saponins: In vitro and in vivo studies. Food and Function, 6(2), 501-512. https://doi.org/10.1039/c4fo00785a

Wachirasiri, P., Julakarangka, S., \& Wanlapa, S. (2009). The effects of banana peel preparations on the properties of banana peel dietary fibre concentrate. Songklanakarin Journal of Science and Technology, 31(6), 605-611.

Wangeci, N. (2011). Characterisation of Crude Pectin Extracted from Banana Peels by Acid Method (Vol. 38). University of Nairobi.

Wayan, B. N., \& Ketut, R. (2015). EFEK BERBAGAI MINYAK PADA METABOLISME KOLESTEROL TERHADAP TIKUS WISTAR. JURNAL KIMIA, 53-60.

Xian, T. K., Omar, N. A., Ying, L. W., Hamzah, A., Raj, S., Jaarin, K., Othman, F., \& Hussan, F. (2012). Reheated palm oil consumption and risk of atherosclerosis: Evidence at ultrastructural level. Evidence-Based Complementary and Alternative Medicine, 2012(Ldl). https://doi.org/10.1155/2012/828170

Yahya, F., Zafar, R., \& Shafiq, S. (2013). Trend of Fast Food Consumption and its Effect on Pakistani Society. Food Science and Quality Management, 6088, 1-8. http://iiste.org/Journals/index.php/FSQM/article/view/3950

Zubaidah, E., Ichromasari, D. Y., \& Mandasari, O. K. (2014). Effect of Salacca vinegar var. Suwaru on lipid profile diabetic rats. Food and Nutrition Sciences, 5(9), 734-748. https://doi.org/10.4236/fns.2014.59084 